\title{
EXAMINATION OF IMPACT OF RESPONSIBLE TOURISM PRACTICES ON QUALITY OF LIFE OF DESTINATION COMMUNITIES
}

\author{
Parikshat Singh MANHAS \\ University of Jammu, Udhampur Campus School of Hospitality and Tourism Management \\ \& The Business School, Jammu Tawi, Jammu \& Kashmir, India, e-mail: psmanhas@ gmail.com
}

\section{Ramjit SINGH}

Central University of Kashmir, Department of Tourism Studies, Ganderbal, Jammu and Kashmir, India, e-mail: ramjitmonu@ yahoo.co.in

\section{Gyula FODOR}

Ferenc Rakoczi II Transcarpathian Hungarian College of Higher Education, Berehove, Department of Earth Sciences and Tourism, Ukraine, e-mail: gyulafodor@ hotmail.com

\section{Sándor BERGHAUER}

Ferenc Rakoczi II Transcarpathian Hungarian College of Higher Education, Berehove, Department of Earth Sciences and Tourism, Ukraine, e-mail: berghauer.sandor@kmf.org.ua

\section{Mudasir Ahmad MIR}

Central University of Kashmir, Department of Tourism Studies, Ganderbal, Jammu and Kashmir, India, e-mail: mirmudasir35@ gmail.com

\section{Lóránt Dénes DÁVID*}

Hungarian University of Agriculture and Life Sciences, Institute of Sustainability and Farming, Department of Sustainable Tourism, Gödöllö, Hungary, e-mail: david.lorant.denes@uni-mate.hu

\author{
Citation: Manhas, P.S., Singh, R., Fodor, G., Berghauer, S., Mir, M.A., \& David, L.D. (2021). EXAMINATION OF IMPACT OF \\ RESPONSIBLE TOURISM PRACTICES ON QUALITY OF LIFE OF DESTINATION COMMUNITIES. GeoJournal of Tourism \\ and Geosites, 36(2spl), 688-697. https://doi.org/10.30892/gtg.362spl17-699
}

\begin{abstract}
The study endeavors to find out the perceived impact of Responsible Tourism Practices (RTPs) on destination communities' Quality of Life (QOL). Besides, the investigation tests the mediating role of community involvement in the relationship between RTPs and QOL. A well-designed questionnaire developed from the existing literature was distributed among the tourist destination residents of Pahalgam, Kashmir Valley, India. In addition, exploratory factor analysis (EFA) and conf irmatory factor analysis (CFA) was performed to validate the EFA findings through AMOSS 22. Structural Equation Modelling (SEM) technique was also applied to ascertain the impact of RTPs on QOL. Finally, the mediating role of community involvement was examined and, subsequently, the results were reported. The study's findings resulted in a significant relationship between RTPs and QOL; thereby, RTPs have a pivotal role in enhancing the QOL of the communities. Furthermore, the investigation revealed that community involvement mediates the relationship between RTPs and QOL. Thus, the study's achievements suggest that the locals should be involved in tourism activities to enhance the communities' QOL.
\end{abstract}

Key words: travel industry, Responsible Tourism Practices, Qualify of Life, destination communities, Pahalgam, mediating factor

\section{INTRODUCTION}

Tourism is considered to be an economic driver for various tourist destinations worldwide (Zhou et al., 1997; Hanafiah and Harun, 2010). Its dominance as a significant income contributor has made it a vital component to the strategic planning efforts and has been widely recognized (Hanafiah and Harun, 2010). Tourism has brought together cultures across the globe (Urry, 2001). Today, there are several challenges that the world is facing in terms of financial instability (Chemingui and Ben Lallouna, 2013), global warming, sustainability issues (Dávid and Baros, 2007), terrorism. There are apparent consequences of these challenges, and a stream of research is being conducted to examine these challenges. Responsible tourism is being considered as an alternative to address these issues (Carasuk, 2011; Husbands and Harrison, 1996).

According to Hanafiah et al. (2016), the association between responsible tourism practices and local communities' quality of life is gaining momentum in the tourism literature. Globally, the debate on responsible tourism practices has received considerable attention due to its full acceptance at the international level (Harrison, 1996), "which regard the host's characteristic, constructed and social conditions (Babbie, 2015) and the interests of all gatherings concerned" (Smith, 1990) and limit "the adverse effects on the destination" (Stanford, 2008). Responsible tourism is considered to be the best tool to minimize the negative impacts of tourism activities at the destination (Crotts and Holland, 1993; Garau-Vadell et al.,

\footnotetext{
* Corresponding author
} 
2018). The travel industry territories' improvement includes different socially cognizant strategies, for example, supporting and ecoing the travel industry, the ethical tourism and other best practices for advancement of the travel industry (Mowforth and Munt, 1998). The tourism industry is people-based and depends on the interaction between them, and is highly sensible to the destination's social and cultural setup (Hanafiah and Harun, 2010) as the tourism industry is facing several issues related to sustainability, resource management, social and economic disparity, fluctuations in the tourist demand. For this reason, destination communities must be benefited from tourism activities to minimize the detrimental effects of tourism, which is why RTPs were incorporated to address all these issues. RTPs have become an essential aspect of tourism research, improving the current manageable tourism practices (Spenceley, 2010).

RTPs focus on maximizing the economic, socio-cultural and environmental benefits of tourism while also dealing with how to minimize these impacts. Besides, RTP is the most favored industry term and approach to set up a travel industry goal for the most part of the African and European countries (Bramwell et al., 2008).

The tourism industry can be developed well with the support and involvement of residents of a destination. As primary stakeholders, destination communities play a significant part in regulating and maintaining the development of tourism. Local community involvement acts as an axiom for successful tourism development at any destination. The local government has to engage the destination communities in tourism activities to get the maximum benefits. This is what the implementation of RTPs focuses upon, as destination communities' attitudes may directly or indirectly influence tourism growth in the destination (Ling and Rani, 2011). As the authorities face difficulties in community involvement while planning and managing tourism at the destination, the RTPs have proven to be a viable tool in easing these difficulties (Shani and Pizam, 2012).

Despite the developing enthusiasm in evaluating the association between the travel industry and QOL and the farreaching learning that the travel industry has an excellent perspective for upgrading the QOL of residents, only a few investigations have assessed the effect of the travel industry on inhabitants' QOL (Kim, 2002; Benckendorff et al., 2009). Though, a study by Hanafiah, 2016 has analysed the relationship between RTPs and QOL, RTPs have been considered as mediators in this relationship. Thus, in the present study the RTPs acted as an independent variable, community involvement has been examined as a mediator in the relationship between the independent variable (RTPs) and dependent variable (QOL). So far no such study has been carried out where it was tested as a mediator in the relationship of RTPs and QOL. To bridge this gap, the investigation directs to evaluate destination communities' perception concerning RTPs and their effect on QOL. More specifically, the study aims to analyse the mediating role of community involvement in enhancing the QOL of destination communities in the light of RTPs.

The present study assesses the residents' perception of the effect of RTPs on their QOL domains in leisure-based tourism destinations, where no such research has been carried out yet. Secondly, this research aims at testing which QOL domain of destination communities is mostly affected through RTPs. These kinds of examinations are vital for both the government and non-government organizations in formulating and executing responsible tourism practices - RTP techniques to produce positive travel industry impacts on inhabitants' QOL. The study presents a thorough review of the impacts of tourism on destination communities' QOL and displays the relevance of linking the RTPs' impacts on their QOL. After the review, a description of empirical examination is introduced, followed by the methodology section in which the data collection techniques are discussed. After this, the results of the study are presented, while in the end the authors explain the practical implications to characterize responsible tourism advancement procedures that improve the residents' QOL.

\section{Theoretical background and hypotheses formulation}

Destination communities' perceptions regarding the effects of tourism development have been researched exhaustively, creating the comparative outcomes of the travel industry's influence on the economic, environmental and social formations of the tourist destinations (Lee, 2013; Hanafiah and Hemdi, 2014). Studies have found out that the local communities perceive tourism as a tool for economic improvement, socio-cultural and ecological preservation (Shani and Pizam, 2012). Some studies, at the same time, have evidenced the contradictory results that destination communities perceive tourism development negatively (Nunkoo and Gursoy, 2012). The development of tourism has great potential to affect the lives of the communities and, subsequently, the residents face challenges related to various aspects of life (Lepp, 2007). Therefore, the tourist destination residents also face challenges, and their quality of life is being largely influenced by tourism activities (Matarrita and Brennan, 2010).

Despite these differences, a few studies have explicitly explored the travel industry's effect on occupants' QOL (Kim et al., 2013). In any case, it is widely perceived that the refinement of occupants' QOL ought to be the priority of the destination management organizations (DMOs). As pointed by Yu et al., 2014, "one of the significant purposes of tourism development in a destination is to improve the Quality of Life (QOL) of the host community." Thus, it is generally perceived that all travel industry improvement systems should be structured and actualized to improve the QOL of all operators, including the locals being a standout amongst the most significant specialists to accomplish a travel industry goal. To evaluate every aspect of the residents' QOL affected by the travel industry advancement, according to Jeon et al. (2016), "residents' quality of life should be conceptualized with an aggregation of residents' perception of economic, social, and environmental conditions as well as the comprehensive perception of well-being in the host community, embracing residents' subjective well-being and objective well-being." Some researchers have contemplated the QOL construct's pertinence in the travel industry and its different areas (Andereck et al. 2007). QOL measure is dependent on four domains: material prosperity (containing two measurements: pay and work and the average cost for essential items), network prosperity, enthusiastic prosperity (calculating two measures: recreation prosperity and profound prosperity) and well-being and security prosperity (Kim, 2002). However, few studies (Hanafiah, 2016; Mathew and Sreejesh, 2017) have analysed the relationship between RTPs and residents' QOL. 
Most of the published investigations are uncovering, that the travel industry affects residents' QOL positively. It may likewise effect locals' QOL contrarily when it adds to the loss of social character (Jeon et al. 2016), causes ecological disturbance, expands average costs for essential items (Liu, 2015), brings in lifestyle changes (Doğan, 1989; Kasim, 2006), creates traffic congestion (Mathieson and Wall, 1982). In this way, the travel industry development does not generally affect the inhabitants' QOL positively. When the travel industry expenses surpass the apparent advantages, it may add to a reduction in inhabitants' QOL. The above context has presented a complete linkage between the tourism development impact studies and residents' QOL. However, there has been a shortage of research that has examined the role of RTPs in communities' QOL. Thus, the present investigation aims at bridging this gap by examining the relationship of RTPs with the residents' QOL. Furthermore, the studies have uncovered a reliable connection between the occupants' satisfaction and recreational facilities, shopping and administration offices (Faulkner and Tideswell, 1997), so we postulate the first hypothesis as follows:

\section{H1: Residents' QOL (Quality of Life) is being influenced by the RTPs (Responsible Tourism Practices)}

Network contribution portrays the degree to which communities are associated with offering concerns about their lives to their networks. A few examinations have surveyed the help of the host inhabitants for the travel industry advancement with an attention on the degree to which these inhabitants are engaged with the travel industry (Simpson, 2001; Goodwin, 2002; Fallon and Kriwoken, 2003; Ndivo and Cantoni, 2016; Rasoolimanesh et al., 2018). Community participation is a fundamental aspect of community-based tourism's (CBT) success (Goodwin and Santilli, 2009). "The involvement of community assumes a critical job in improving network-based travel industry because network investment can build the estimation of a network by upgrading the beneficial outcomes of the travel industry and diminishing its negative impacts" (Jamal and Getz, 1995). Given the idea that native support must be joined by power redistribution, Arnstein (1969) built up a stepping stool of domestic investment as a model to clarify the natural transformative strides of this procedure.

As per this model, three dimensions of slow development, comprising non-cooperation, degrees of tokenism and degrees of inherent power are utilized to evaluate network inclusion and investment in the network-based travel industry (Okazaki, 2008; Selin and Chavez, 1995). The travel industry studies demonstrate that drawing in the community participation in the board and essential leadership can persuade the network of the need to incorporate the travel industry into the local economy (Simpson, 2001; Wang, and Pfister, 2008; Sebele, 2010; Bello et al., 2018). Engagement of the host community in the tourism-related activities opens new doors of profit for the locals (Sebele, 2010).

A few researchers of the travel industry have utilized the seen advantages and expenses as the mediating factors of community involvement for the travel industry advancement (Nicholas et al., 2009), also as the ecological frame of mind (Gursoy et al., 2002; Nicholas et al., 2009) and as a method for evaluating hypothetical models. Butcher (1997), likewise, proposed that both immediate and circuitous community involvement are valuable because both reinforce the benefit base of practical improvement of the travel industry. Accordingly, this examination states that inhabitants with economic travel industry improvement frames of mind will be effectively linked with network associations and open undertakings. Along these lines, community involvement may have an interceding impact between RTPs and QOL of local communities. Thus, the present investigation has formulated the second hypothesis:

H2: Community involvement mediates the connection between RTPs (Responsible Tourism Practices) and QOL (Quality of Life)

\section{Research framework}

The present examination aims at evaluating the perceived impact of responsible tourism practices on the quality of life of communities/residents in the Kashmir Valley. As was said before, the study also tests the mediating role of community involvement in the relationship between RTPs and QOL. An exhaustive literature review was conducted related to these variables and, consequently, a research framework was developed (Figure 1). The exploration structure embraced for the present investigation covers the examination's objectives, which incorporate all the measurements that shape and impact communities' perception regarding RTPs.

\section{RESEARCH METHODOLOGY}

For the present study both the primary and secondary data have been used to evaluate the role of RTPs in the local community's Quality of Life and the relationship between these two variables in the presence of a mediator - community involvement (Mertler and Vannatta, 2004). The secondary data was collected from various international and national journals and reports. The primary data was compiled through a questionnaire drafted on existing literature and distributed among the residents of the Pahalgam destination.

\section{Research Instrument}

Host communities' perception of the significance of RTPs in the QOL of communities was measured through a scale developed by considering the previous literature (Chiappa et al., 2016, Hanafiah, 2016; Mathew and Sreejesh, 2017). It consisted of 20 items, measured on a five-point Likert type scale, where grade 1 represented strong disagreement, grade 5 - strong agreement. The second construct, i.e. the Quality of life, was developed from the study of Kim, Uysal and Sirgy (2013) and was measured on a five-point Likert type scale (from $1=$ strong disagreement to $5=$ strong agreement). The mediator, i.e. the community involvement, was adopted from the studies of Lee, 2013; Cheng et al., 2017 and was subsequently measured on a fivepoint Likert scale, too. To extract dimensions from responsible tourism and QOL, Exploratory Factor Analysis (EFA) was carried out. To validate the EFA, Confirmatory Factor Analysis (CFA) was also applied. Finally, the Structured Equation Model $(\boldsymbol{S E M})$ was used to test the proposed hypotheses and to evaluate the effect of responsible tourism practices on QOL. 


\section{Sampling Design}

The study was conducted in Pahalgam, a famous tourist destination, Kashmir region, Jammu, and Kashmir, India. The study sample was created from the residents whose age was 18 years or above, living in the selected villages. The sample frame was obtained from the electoral roll record of 2011 of the concerned Block Development Officer (BDO) area. The method of collecting quantitative data from the respondents' sample of these identified and independent sampling units has been systematic. Initially, the sampling interval was obtained using the formula (total number of household residents, collected from the electoral voter list / sample size obtained applying the formula of Taro Yamane).

Using the random number table, we selected a family number between 1 and the obtained sampling interval. These families were then contacted via door-to-door format to gather information.

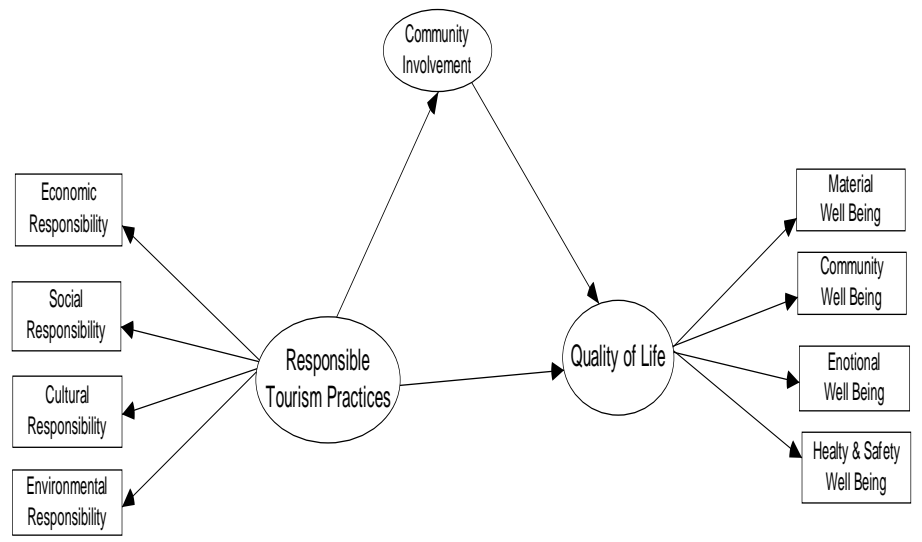

Figure 1. The Research Framework (Source: own compilation)
Table 1. Results of the Reliability Test (Source: own compilation)

\begin{tabular}{|c|c|c|}
\hline Dimensions & \begin{tabular}{|l|} 
No. of \\
items
\end{tabular} & $\begin{array}{c}\text { Cronbach } \\
\text { Alpha }(\alpha) \text { Value }\end{array}$ \\
\hline Economic Responsibility & 04 & .912 \\
\hline Social Responsibility & 03 & .865 \\
\hline Cultural Responsibility & 03 & .838 \\
\hline Environmental Responsibility & 04 & .913 \\
\hline Responsible Tourism Practices (RTPs) & 14 & .863 \\
\hline Material Well-being & 03 & .882 \\
\hline Community Well-being & 03 & .859 \\
\hline Emotional Well-being & 02 & .706 \\
\hline Health and Safety Well-being & 03 & .766 \\
\hline Quality of Life (OOL) & 11 & .805 \\
\hline Community Involvement & 05 & .935 \\
\hline
\end{tabular}

\section{Sample Size}

Selection of optimum sample size is the researchers' core concern to come up with a reliable study. The present study sample was calculated using the Taro Yamane (1973) formula with a 95\% confidence level. The formula of Taro Yamane is presented as follows.

$$
n=\frac{N}{1+N(e) 2} \quad \text { where: } \quad \begin{aligned}
& \mathrm{n}=\text { sample size required } \\
& \mathrm{N}=\text { number of people in the population } \\
& \mathrm{e}=\text { allowable error }(\%)
\end{aligned}
$$

As per the Block Development Officer, the destination's electoral roll (core zone) as of September 2018 was 2367. Therefore, the sample size by using the Taro Yamane (1973) formula for the study was 342.

\section{DATA ANALYSIS AND RESULTS}

Initially, problems related to missing values and outliers were experienced. Then reliability was checked through the Cronbach Alpha $(\alpha)$. The results of Cronbach Alpha $(\alpha)$ were above the threshold level of $\mathbf{0 . 6 0}$ (Table 1), thus indicating the internal consistency (Nunnally, 1978). The normality of the variables was checked through skewness and kurtosis and was in the range of \pm 2.00 , indicating the data's normality. As indicated in Table 2, 57.3\% $(\mathrm{n}=196)$ of respondents were males, while 42.7\% $(\mathrm{n}=146)$ were females. Approximately $41 \%(\mathrm{n}=141)$ of households were residing there for the last 10-20 years. The majority of the participants were associated with the local business $(59 \%, \mathrm{n}=87)$, and only $16 \%(\mathrm{n}=23)$ were involved in governmental jobs. Most of the respondents were between $31-43$ years $(43 \%, \mathrm{n}=135)$. The respondents' majority $(44 \%, \mathrm{n}=152)$ was directly involved in the tourism activities at the destination.

Table 2. Demographic profile of the respondents (Source: own compilation)

\begin{tabular}{|l|c|c|c|c|}
\hline \multicolumn{5}{|c|}{ Profile of respondents (Demographic) } \\
\hline Age & 18 to 30 years (28.9\%) & 31 to 43 years (39.5\%) & 44 to 56 years (22.2\%) & 57 and above (9.4\%) \\
\hline Gender & Male (57.3\%) & Female (42.7\%) & & Others (6\%) \\
\hline Occupation & Local Business (59\%) & Govt. Job (16\%) & Professionals (19\%) & above 30 years $(9.1 \%)$ \\
\hline Years of Residency & $1-10$ years (18.1\%) & $10-20$ years (41.2\%) & $20-30$ years (31.6\%) & \\
\hline Household & Less than Rs. & Rs. 1,00,000- Rs. & Above Rs. & \\
income (annual) & $1,00,000(32.7 \%)$ & $2,00,000(51.2 \%)$ & $2,00,00(16.1 \%)$ & not employed \\
\hline $\begin{array}{l}\text { Involvement in } \\
\text { tourism }\end{array}$ & directly employed & $\begin{array}{c}\text { indirectly employed } \\
(44.4 \%)\end{array}$ & $(31.9 \%)$ & $\begin{array}{c}\text { employed in the tourism industry } \\
\text { other than my village (10.2\%) }\end{array}$ \\
\hline
\end{tabular}

\section{Factor Analysis Results}

To extract the Responsible Tourism Practices (RTPs) and Quality of Life (QOL) factors Principal Component analysis and VARIMAX Rotation with Kaiser Normalization were performed. The scale consisted of $\mathbf{1 4}$ items for RTPs and $\mathbf{1 1}$ items for QOL. The 14 items of RTPs got converted into 04 factors, namely Economic (04 items), Social (03 items), Cultural (03 items) and Environmental (04 items) responsibilities, and accounted for 78.714\% variance. The value of Kaiser-Meyer-Olkin (KMO) test for Responsible Tourism Practices was .832, indicating an adequate EFA sample. 
Table 3. Results of the Exploratory Factor Analysis with descriptive statistics (Source: own compilation)

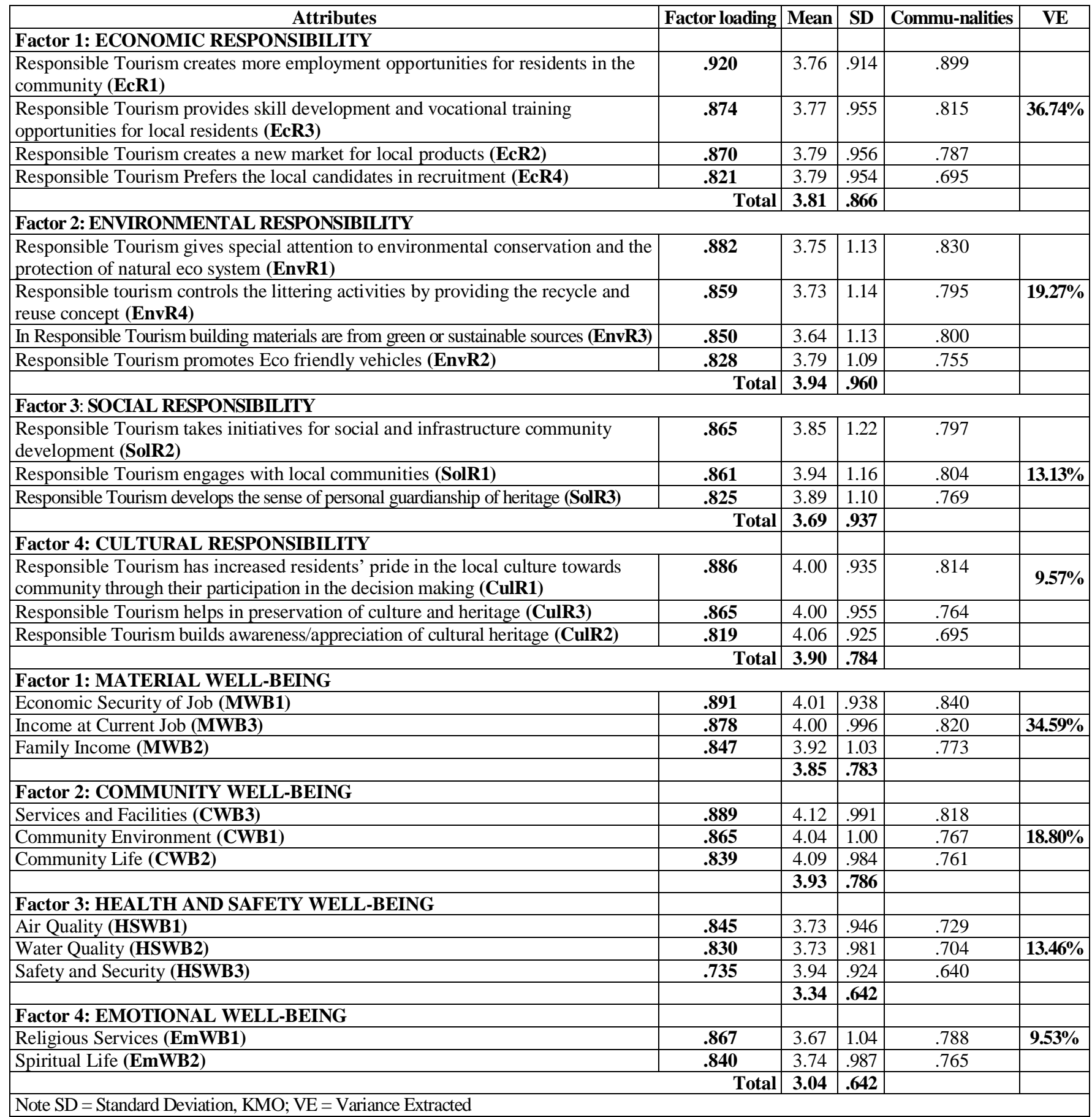

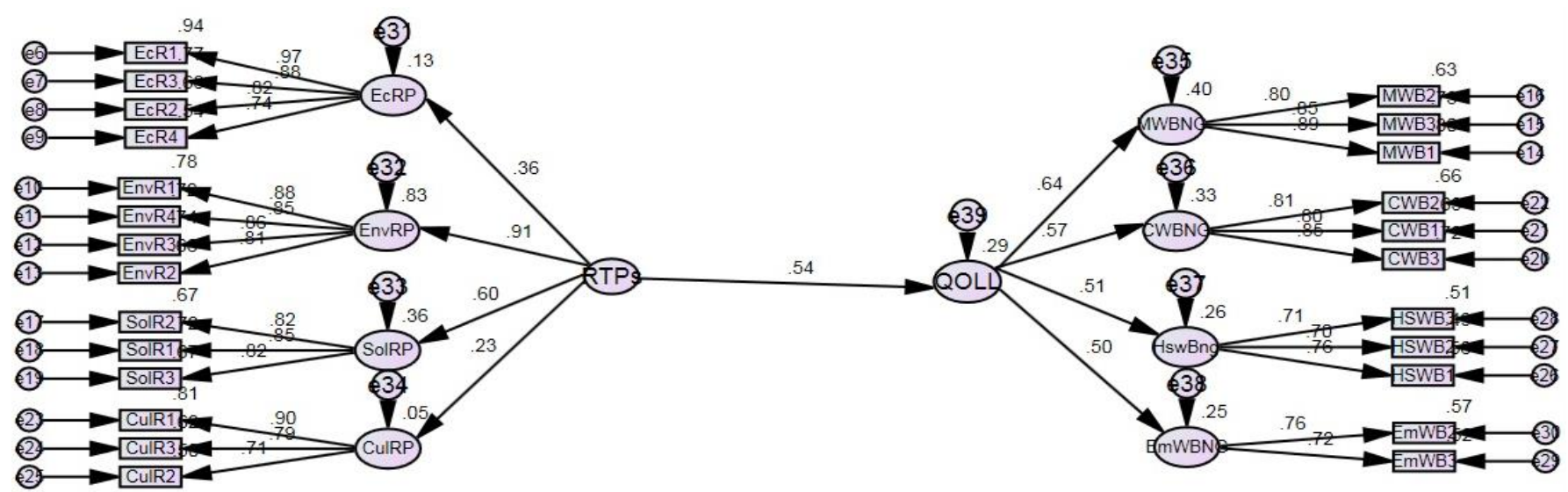

Figure 2. Relationship between the RTPs and the QOL (Source: own compilation) 
The 11 items of Quality of Life were extracted into 04 factors as well, namely: Material Well-being (03 items), Community Well-being (03 items), Emotional Well-being (02 items), Health and Safety Well-being (03 items). The results of KaiserMeyer-Olkin (KMO) test for QOL was .716, thus affirming the EFA data suitability. The value for Bartlett's test of Sphericity appeared to be $\mathbf{3 1 1 5 . 6 6}$ for RTPs (.000 significance with a degree of freedom 91) and 1696.08 for QOL (.000 significance with a degree of freedom 55), thereby indicating that factors are related to each other. One item for Emotional Well-being (Cultural Exchange) got deleted because of the cross-loading. Table 3 shows the results of the exploratory factor analysis.

Table 4. Results of the Confirmatory Factor Analysis (Source: own compilation)

\begin{tabular}{|l|c|c|c|c|}
\hline \multicolumn{1}{|c|}{ Dimensions } & Items & Loadings & AVE & CR \\
\hline \multirow{2}{*}{ Economic } & EcR1 & $\mathbf{. 9 6 9}$ & & \\
Responsibility & EcR3 & $\mathbf{. 8 7 8}$ & & \\
& EcR2 & $\mathbf{8 2 3}$ & $\mathbf{0 . 7 3 3}$ & $\mathbf{0 . 9 1 6}$ \\
& EcR4 & $\mathbf{. 7 3 7}$ & & \\
\hline & EnvR1 & $\mathbf{. 8 8 5}$ & & \\
Environmental & EnvR4 & $\mathbf{. 8 4 5}$ & & \\
Responsibility & EnvR3 & $\mathbf{. 8 5 7}$ & $\mathbf{0 . 7 2 5}$ & $\mathbf{0 . 9 1 3}$ \\
& EnvR2 & $\mathbf{. 8 1 7}$ & & \\
\hline Social & SolR2 & $\mathbf{. 8 1 6}$ & & \\
Responsibility & SolR1 & $\mathbf{. 8 5 0}$ & $\mathbf{0 . 6 8 4}$ & $\mathbf{0 . 8 6 6}$ \\
& SolR3 & $\mathbf{. 8 1 4}$ & & \\
\hline Cultural & CulR1 & $\mathbf{. 8 9 7}$ & & \\
Responsibility & CulR3 & $\mathbf{. 7 8 8}$ & $\mathbf{0 . 6 4 3}$ & $\mathbf{0 . 8 4 3}$ \\
& CulR2 & $\mathbf{. 7 1 0}$ & & \\
\hline Material Well- & MWB1 & $\mathbf{. 8 8 3}$ & & \\
Being & MWB3 & $\mathbf{. 8 5 8}$ & $\mathbf{0 . 7 1 9}$ & $\mathbf{0 . 8 8 5}$ \\
\hline Community & CWWB2 & $\mathbf{. 8 0 1}$ & & \\
Well-Being & CWB1 & $\mathbf{. 8 5 0}$ & & \\
\hline Health and & CWB2 & $\mathbf{. 7 8 6}$ & $\mathbf{0 . 6 7 0}$ & $\mathbf{0 . 8 5 9}$ \\
Safety Well- & HSWB1 & $\mathbf{. 7 4 8}$ & & \\
Being & HSWB2 & $\mathbf{. 6 9 1}$ & $\mathbf{0 . 5 2 4}$ & $\mathbf{0 . 7 6 7}$ \\
\hline Emotional & HSWB3 & $\mathbf{. 7 3 1}$ & & \\
Well-Being & EmWB1 & $\mathbf{. 7 2 2}$ & & \\
\hline & EmWB2 & $\mathbf{. 7 5 7}$ & $\mathbf{0 . 5 4 7}$ & $\mathbf{0 . 7 0 7}$ \\
\hline Community & CInv4 & $\mathbf{. 9 3 2}$ & & \\
Involvement & CInv2 & $\mathbf{. 9 0 0}$ & & \\
& CInv5 & $\mathbf{. 8 5 5}$ & $\mathbf{0 . 7 4 5}$ & $\mathbf{0 . 9 3 6}$ \\
& CInv1 & $\mathbf{. 7 8 3}$ & & \\
\hline & CInv3 & $\mathbf{. 8 3 8}$ & & \\
\hline
\end{tabular}

Note:

$\mathrm{X}^{2}=$ Chi-square; $\mathrm{df}=$ degree of freedom;

GFI = goodness of fit index;

AGFI $=$ adjusted goodness of fit index;

$\mathrm{CFI}=$ comparative fit index;

IFI =incremental fit index;

RMSEA $=$ root mean square error of approximation; AVE $=$ average variance extracted, $\mathrm{CR}=$ composite reliability

$\begin{array}{ll}\begin{array}{l}\text { Goodness of fit } \\ \text { indices }\end{array} \\ \text { XFI) } \\ \text { X2 } & 558.183 \\ \text { df } & 370 \\ \text { GFI } & 0.906 \\ \text { AGFI } & 0.883 \\ \text { CFI } & 0.970 \\ \text { IFI } & 0.971 \\ \text { RMSEA } & 0.039\end{array}$

\section{Measurement model}

A measurement model with nine factors, including the mediator (community involvement), was tested by confirmatory factor analysis. The results indicate the suitability of the data for model fit. Chi-square $=\mathbf{5 5 8 . 1 8 3}$, with degree of freedom $=370$ at probability level $=.000(\mathrm{P}<$ $0.05), C M I N / D F=1.509, G F I=0.906, A G F I=$ $0.882, C F I=0.970, I F I=0.971, T L I=0.965$, $\boldsymbol{R M S E A}=\mathbf{0 . 0 3 9}$. The results of the CFA indicate that the data fits the model very well.

Table 5 shows the convergent validity and discriminant validity results, thus affirming the Composite Reliability (CR). The table results depict that the values of CR are higher than the threshold value of 0.60 (Koufteros, 1999), which reconfirms the convergent validity (internal consistency of variables).

Besides the $\mathrm{CR}$ values, the values of the average variance extracted (AVE) were also higher than the suggested threshold value of $\mathbf{0 . 5 0}$ (Fornell and Larcker, 1981). These results verify the convergent validity of the dimensions measured. Furthermore, we examined the constructs' discriminant validity by examining the square of all the pairs of correlations with AVE values. The values of the square root of the AVE were higher than the values of the correlation coefficients (Fornell and Larcker, 1981), presenting hereby the proof for discriminant validity.

Table 5. Results of the Convergent Validity and the Discriminant Validity (Source: own compilation)

\begin{tabular}{|c|c|c|c|c|c|c|c|c|c|c|c|}
\hline & CR & AVE & HswBng & CoInv & EcRP & EnvRP & MWBNG & SolRP & CWBNG & CulRP & EmWBNG \\
\hline HswBng & 0.767 & 0.524 & 0.724 & & & & & & & & \\
\hline CoInv & 0.936 & 0.745 & 0.199 & 0.863 & & & & & & & \\
\hline EcRP & 0.916 & 0.733 & 0.118 & 0.229 & 0.856 & & & & & & \\
\hline EnvRP & 0.913 & 0.725 & 0.186 & 0.222 & 0.315 & 0.851 & & & & & \\
\hline MWBNG & 0.885 & 0.719 & 0.337 & 0.310 & 0.155 & 0.289 & 0.848 & & & & \\
\hline SolRP & 0.866 & 0.684 & 0.117 & 0.092 & 0.218 & 0.554 & 0.145 & $\mathbf{0 . 8 2 7}$ & & & \\
\hline CWBNG & 0.859 & 0.670 & 0.424 & 0.349 & 0.112 & 0.425 & 0.262 & 0.147 & 0.818 & & \\
\hline CulRP & 0.843 & 0.643 & 0.012 & 0.204 & 0.335 & 0.173 & 0.166 & 0.156 & 0.051 & 0.802 & \\
\hline EmWBNG & 0.707 & 0.547 & 0.123 & 0.275 & 0.073 & 0.199 & 0.503 & 0.049 & 0.192 & 0.109 & 0.740 \\
\hline
\end{tabular}

\section{Structural Model and Hypotheses Testing}

After the confirmatory factor analysis the next step was to test the proposed set of hypotheses through SEM.

The results of the model showed that the data fits it very well. Chi-square $=\mathbf{5 0 2 . 2 0 2}$, with degrees of freedom $=267$ at probability level $=.000(p<0.05) ; C M I N / D F=1.881 ; G F I=0.900 ; A G F I=0.878 ; C F I=0.951 ; I F I=0.951 ; T L I=0.945$; $\boldsymbol{R M S E A}=0.051$. The results of structural equation modelling, along with path coefficient are shown in the Figure 2 . The study revealed that Responsible Tourism Practices explained a 29\% variance on the communities' QOL. From the examination of way coefficients it was discovered that QOL is being influenced by the RTPs $(\boldsymbol{\beta}=\mathbf{0 . 5 4}, \boldsymbol{p}<\mathbf{0 . 0 5})$.

\section{Results of the Mediation Test}

To analyze the mediating effect of community involvement between responsible tourism practices and communities' quality of life, the sample number was set to 2000 . The $95 \%$ confidence interval was obtained by the help of the bootstrap 


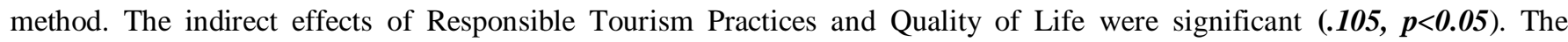
examination of the direct path of RTPs on QOL in the presence of a mediator (community involvement) showed that the direct impact was also significant $(.450, p<0.05)$. Thus, we could indicate the mediating effect of community involvement in the relationship between the responsible tourism practices and quality of life.

\section{DISCUSSION AND IMPLICATIONS}

The study undertook to assess the relationship between the Responsible Tourism Practices (RTPs) and Quality of Life (QOL), and also check the role of RTPs in enhancing the QOL of the destination communities. Besides, the study endeavoured to analyze the mediating effect of community involvement in the relationship between $\mathrm{R}$.

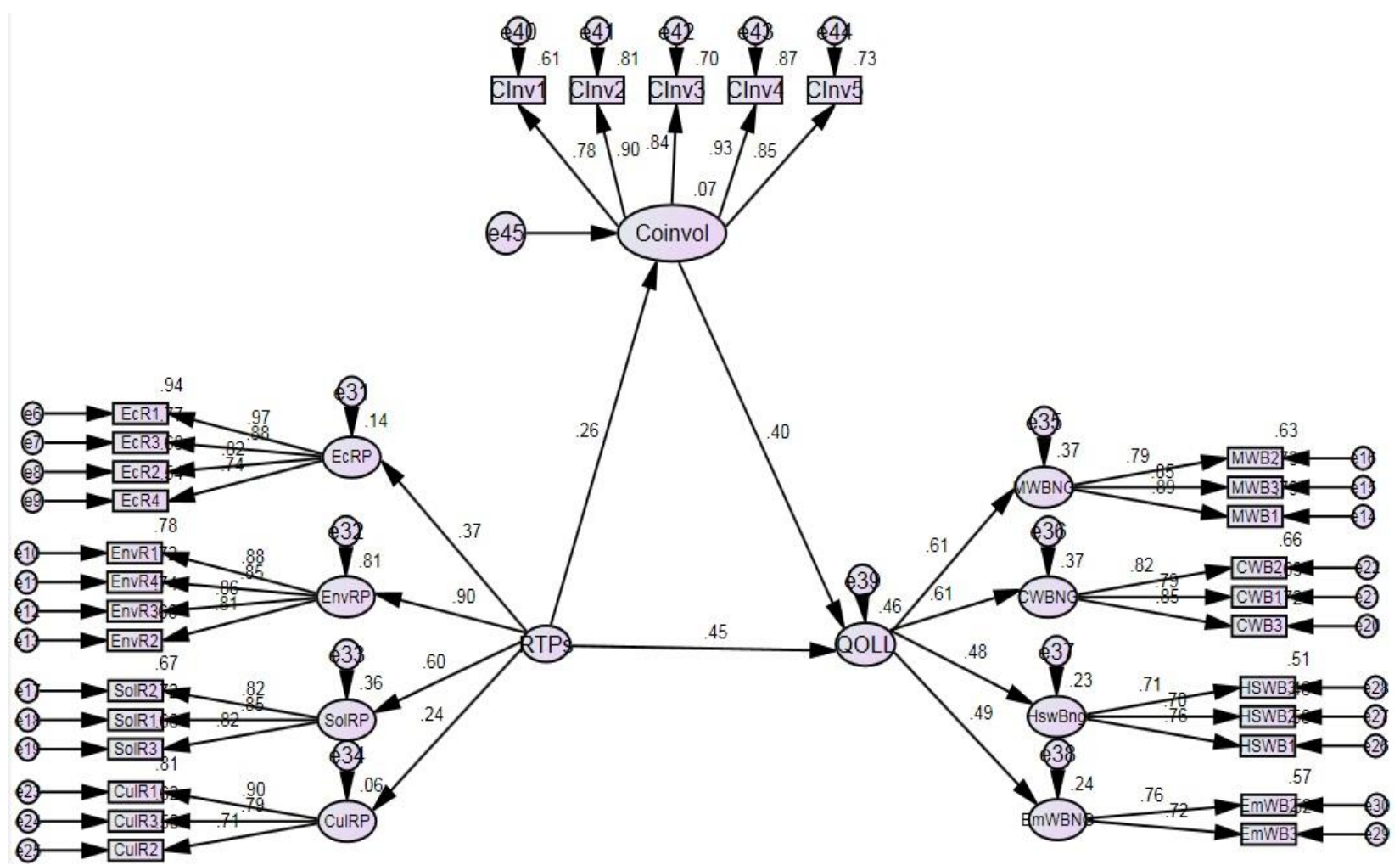

Figure 3. The mediating effect of community involvement (Source: own compilation)

TPs and QOL. The study's findings revealed that host communities perceive that both RTPs and QOL consist of four $2^{\text {nd }}$ order constructs: Economic Responsibility, Environmental Responsibility, Social Responsibility, Cultural Responsibility and Material Well-Being, Community Well-Being, Emotional Well-Being, Health and Safety Well-Being respectively. The

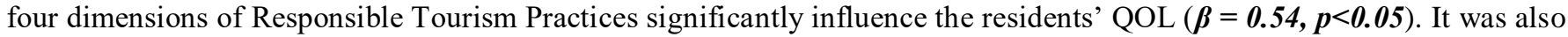
found out that destination communities perceive the important role of RTPs in enhancing their quality of life. The findings of the investigation uncovered that RTPs are a crucial indicator to impact the QOL of host communities.

The majority of respondents agreed that RTPs create more employment opportunities for residents in the community $(\boldsymbol{m e a n}=3.76 ; \boldsymbol{E c R I})$, provide skill development and vocational training opportunities for them $(\boldsymbol{m e a n}=3.77 ; \boldsymbol{E} \boldsymbol{c R 3})$ and create a new market for the local products (mean $=3.79 ; \boldsymbol{E} \boldsymbol{c R 2})$. Likewise, residents agreed that RTPs engage the local communities $(\boldsymbol{m e a n}=3.94$; SolR1 $)$, take initiatives for social and infrastructural community development $(\boldsymbol{m e a n}=3.85$; SolR2), develop a sense of personal guardianship of the heritage (mean $=3.89$; SolR3), increase residents' pride in the local culture towards the community through their participation in the decision making $(\boldsymbol{m e a n}=\mathbf{4 . 0 0 ;}$ CulR $)$, build awareness/ appreciation of the cultural heritage (mean $=4.06$; $\mathbf{C u l R 2})$. Furthermore, the practices drive special attention to environmental conservation and the protection of the natural ecosystem (mean = 3.75; EnvRI), control the littering activities by providing the recycle and reuse concept $(\boldsymbol{m e a n}=3.73 ; \boldsymbol{E n v R 4})$, promote the eco-friendly vehicles $(\boldsymbol{m e a n}=$ 3.79; EnvR2) and the building materials from green or sustainable sources (mean = 3.64; EnvR2).

The results of the study revealed that the Material Well-Being domain of the Quality of Life has the highest variance $\mathbf{( 3 4 . 5 9 \% )}$. The factors inside it are appraised as generally essential to inhabitants, like Economic Security of Job $(\boldsymbol{m e a n}=\mathbf{4 . 0 1}$; MWB1), Income at Current Job (mean $=4.00 ; M W B 3)$ or Family Income (mean = 4.01; MWB2), followed by Community Well-Being that shows a $\mathbf{1 8 . 8 0 \%}$ variance with the item Services and Facilities (CWB3), having a mean value of 4.12, Community life (CWB2) with a mean value of $\mathbf{4 . 0 9}$ and Community environment (CWB1) with a mean value of 4.04. The third construct of Quality of Life, Health and Safety Well-Being has a 13.46\% variance. The items in this variable comprise of Safety and Security (HSWB3), having a mean value of 3.94, followed by Air Quality (HSWB1) with a mean value of $\mathbf{3 . 7 3}$ and Water Quality (HSWB2) making up a mean value also of 3.73. The fourth dimension of Quality of Life, Emotional WellBeing, shows a $9.53 \%$ variance. In this construct, the item Spiritual Life (EmWB2) has the highest mean value of 3.74, 
followed by Religious Services (EmWB1) with a mean value of 3.67. As it is evident from the SEM results, Responsible Tourism Practices (RTPs) have the highest impact on Environmental Responsible Practices (EnRP) $(\boldsymbol{\beta}=\mathbf{9 1 ;} \boldsymbol{p}<\boldsymbol{0 . 0 5}$ ), thus indicating that ERP has a tremendous role in RTPs. This is why DMOs should incorporate environmentally responsible practices at tourist destinations for proper implementation of RTPS. It can be achieved by implementing eco-friendly procedures like reducing waste production and it's recycling, avoiding the use of plastic cutlery, applying reusable bags and containers, having alternative sources of energy like solar batteries etc. Through this, the negative environmental impacts can be minimized and the destination sustainability can be achieved. Besides, it is also suggested to use local materials and implement local architecture while designing any tourist destination infrastructure.

It is evident from the results that there is a moderate contribution of Cultural Responsible Practices (CuRP) $(\boldsymbol{\beta}=.23$; $\boldsymbol{p}<\mathbf{0 . 0 5}$ ), thereby indicating that much attention needs to be given while incorporating Responsible Tourism Practices at a particular tourist destination. The authorities concerned should promote heritage sites, monuments and landmarks, museums and exhibitions through various social media platforms to encourage visiting the valley in order to gain a rich cultural experience. Thus, the earned income can be used to preserve the rich cultural heritage of the destination. DMOs should develop responsible tourism with dignity, respecting and nurturing local cultures (including religion) to enrich the tourism experience and build pride and confidence among the local communities. Besides, sufficient support has to be given to developing sustainable local handicraft enterprises by improving the design, production, packaging and marketing skills of the craft workers adapting to the market demand. It is also suggested to encourage the production of local cultural products, crafts and artefacts so that the local community could get the maximum benefits from the tourism activity. Through these practices, the destination's rich cultural heritage can be sustained for a longer period. Accordingly, the destinations can become competitive by offering the tourists a unique and rich cultural experience.

The findings of the study have revealed that Economic Responsible Practices (EcRP) have a better contribution $(\boldsymbol{\beta}=\mathbf{. 3 6}$; $\boldsymbol{p}<\mathbf{0 . 0 5}$ ) towards RTPs. So, tourism authorities should give due consideration while incorporating the Economic Responsible Practices in RTPs so that by implementing RTPs the QOL of destination communities could be enhanced. For these, best employment opportunities for locals, various economically rich initiatives (like developing niche products based on local raw materials) should be created. The small, medium and micro-enterprises should be encouraged to employ locals and enhance their service standards in order to maximize their revenue potential. Furthermore, the focus should be given to encouraging tourists to buy locally made products and to use locally produced services from locally operated businesses, so that the best of the economically responsible tourism practices could be utilized and implemented. It is also suggested that locals must be consulted while designing any policy and strategy regarding the responsible tourism practices. It is of utmost importance to promote awareness concerning responsible tourism's potential benefits to QOL among the residents.

The results of the research have also disclosed that Community Well-Being $(\mathrm{CuWB})$ has the highest impact $(\boldsymbol{\beta}=. \mathbf{5 7}$; $\boldsymbol{p}<\mathbf{0 . 0 5}$ ) on the quality of life. This means that it is a good predictor of QOL. Based on the indicators proposed in the study, Services and Facilities (CWB3), Community environment (CWB1) and Community life (CWB2) have to be taken to the fore of the agenda of tourism. Due consideration should be given to these indicators to enhance the QOL of destination communities. It is also revealed that Health and Safety Well-Being $(\mathrm{HsWB})$ has the lowest contribution $(\boldsymbol{\beta}=. \mathbf{5 1} ; \boldsymbol{p}<\boldsymbol{0 . 0 5})$ towards QOL, thus indicating that communities do not perceive much contribution in this regard. A possible reason for this might be that destination communities are not so health-conscious. As it was said before, community involvement has a mediating role between the relationship of RTPs and QOL of communities. Therefore, governments and local authorities should focus on locals' participation in tourism activities to enhance their QOL. This can be achieved by the involvement of locals in the decision-making process and by giving more opportunities for communities to participate in tourism-related activities, for example, privileging the locals in employment to realize the tourism's actual benefits. Besides, promotional campaigns and programs should emphasize the involvement of locals. Their increased participation in tourism-related activities is crucial for the support of Responsible Tourism Practices. Thus, the research results offer a significant insight for local authorities in community participation for the advancement and development of responsible tourism practices.

\section{CONCLUSION AND DIRECTIONS FOR FUTURE STUDIES}

The findings of the investigation revealed a positive relationship between RTPs and QOL, and that responsible tourism practices have a significant role in enhancing the quality of life of the destination communities. The results proved that community involvement mediates the relationship between RTPs and QOL. To sum these up, we can state that the communities' perception of Responsible Tourism Practices incorporates the economic, socio-cultural and environmental dimensions that influence the destination domains' quality of life. Despite its commitments, this investigation has a few limitations that ought to be expanded in the future research. This study focused only on one destination community. Examination of various types of local communities, such as native networks, horticultural networks etc. may lead to contrary conclusions for implementing responsible tourism practices. Future studies should lead to comparable results over a wide range of destination communities to overcome this impediment. Given the need to survey the impacts of RTPs and QOL on support for the practical advancement of RTPs, the future research ought to thoroughly inspect this conduct model regarding the host communities by testing the community involvement as a moderator. Subsequently, it is important to evaluate, whether this model can be connected to different network-based types in the travel industry.

Besides, only communities directly associated with the tourism activities were examined. It would be intriguing to study the perceptions of those that are not associated with the tourism phenomenon or not involved in tourism. Future research has to include them as well and also the others that are most certainly not engaged with the travel industry improvement at all. These communities must be looked at by the moderating effect of community involvement in the travel industry. As the present 
study's design was cross-sectional, longitudinal sectional studies should be carried out to test the mediation effect of community involvement with other variables such as community attachment and support for future tourism.

\section{REFERENCES}

Andereck, K.L., Valentine, K.M., Vogt, C.A. \& Knopf, R.C. (2007). A cross-cultural analysis of tourism and quality of life perceptions. Journal of Sustainable Tourism, 15 (5), 483-502. https://doi.org/10.2167/jost612.0

Arnstein, S.R. (1969). A ladder of participation. Journal of the American Planning Association, 35 (4), 216-224. https://doi.org/10.1080/ 01944366908977225

Babbie, E. (2015). The practice of social research. Cengage Learning, Boston, MA, US (e-book format).

Bello, F.G., Lovelock, B. \& Carr, N. (2018). Enhancing community participation in tourism planning associated with protected areas in developing countries: Lessons from Malawi. Tourism and Hospitality Research, 18 (3), 309-320. https://doi.org/10.1177/1467358416647763

Benckendorff, P., Edwards, D., Jurowski, C., Liburd, J.J., Miller, G. \& Moscardo, G. (2009). Exploring the future of tourism and quality of life. Tourism and Hospitality Research, 9 (2), 171-183. https://doi.org/10.1057/thr.2009.7

Bramwell, B., Lane, B., McCabe, S., Mosedale, J. \& Scarles, C. (2008). Research perspectives on responsible tourism. https://doi.org/10.1080/09669580802208201

Butcher, J. (1997). Sustainable development or development? In: M. J. Stabler (Ed.), Tourism and sustainability: Principles to practice, $27-$ 38. New York, NY: CAB International. https://doi.org/10.1177/004728759803700150

Carasuk, R. (2011). Responsible Tourism Qualmark Accreditation: A comparative evaluation of tourism businesses and tourists' perceptions.

Chemingui, H. \& Ben Lallouna, H. (2013). Resistance, motivations, trust and intention to use mobile financial services. International Journal of Bank Marketing, 31 (7), 574-592. https://doi.org/10.1108/IJBM-12-2012-0124

Cheng, T. M., Wu, H. C., Wang, J. T. M. \& Wu, M. R. (2017). Community Participation as a mediating factor on residents' attitudes towards sustainable tourism development and their personal environmentally responsible behaviour. Current Issues in Tourism, 1-19. https://doi.org/10.1080/13683500.2017.1405383

Chiappa, G.D., Grappi, S., \& Romani, S. (2016). Attitudes Toward Responsible Tourism and Behavioral Change to Practice it: A DemandSide Perspective in the Context of Italy. Journal of Quality Assurance in Hospitality \& Tourism, 17 (2), $191-208$. https://doi.org/10.1080/1528008X.2015.1115254

Crotts, J.C. \& Holland, S.M. (1993). Objective indicators of the impact of rural tourism development in the state of Florida. Journal of Sustainable Tourism, 1 (2), 112-120. https://doi.org/10.1080/09669589309514805

Dávid, Lóránt \& Baros, Zoltán (2007). A possible use of indicators for sustainable development of tourism. ANATOLIA: An international journal of tourism and hospitality research 18 (2), 349-355. https://doi.org/10.1080/13032917.2007.9687211

Doğan, H.Z. (1989). Forms of adjustment: Sociocultural impacts of tourism. Annals of tourism research, 16 (2), $216-236$. https://doi.org/10.1016/0160-7383(89)90069-8

Fallon, L.D. \& Kriwoken, L.K. (2003). Community involvement in tourism infrastructure - the case of the Strahan Visitor Centre, Tasmania. Tourism Management, 24 (3), 289-308. https://doi.org/10.1016/S0261-5177(02)00072-9

Faulkner, B. \& Tideswell, C. (1997). A framework for monitoring community impacts of tourism. Journal of sustainable tourism, 5 (1), 3 28. https://doi.org/10.1080/09669589708667273

Fornell, C. \& Larcker, D.F. (1981). Evaluating structural equation models with unobservable variables and measurement error. Journal of Marketing Research, 18 (1), 39-50. https://doi.org/10.2307/3151312

Garau-Vadell, J.B., Gutierrez-Taño, D. \& Diaz-Armas, R. (2018). Economic crisis and residents' perception of the impacts of tourism in mass tourism destinations. Journal of destination marketing \& management, 7, 68-75. https://doi.org/10.1016/j.jdmm.2016.08.008

Goodwin, H. (2002). Local community involvement in tourism around national parks: opportunities and constraints. Current Issues in tourism, 5 (3-4), 338-360. https://doi.org/10.1080/13683500208667928

Goodwin, H. \& Santilli, R. (2009). Community-based tourism: A success. ICRT Occasional paper, 11 (1), 37.

Gursoy, D. \& Kendall, K.W. (2006). Hosting mega-events: Modelling locals' support. Annals of tourism research, 33 (3), $603-623$. https://doi.org/10.1016/j.annals.2006.01.005

Gursoy, D. \& Rutherford, D.G. (2004). Host attitudes toward tourism: An improved structural model. Annals of Tourism Research, 31 (3), 495-516. https://doi.org/10.1016/j.annals.2003.08.008

Gursoy, D., Jurowski, C. \& Uysal, M. (2002). Resident attitudes: A structural modelling approach. Annals of tourism research, 29 (1), 79105. https://doi.org/10.1016/S0160-7383(01)00028-7

Hanafiah, M.H.M. \& Harun, M.F.M. (2010). Tourism demand in Malaysia: A cross-sectional pool time-series analysis. International Journal of trade, economics and Finance, 1 (1), 80-83. https://doi.org/10.7763/IJTEF.2010.V1.15

Hanafiah, M.H. \& Hemdi, M.A. (2014). Community behaviour and support towards island tourism development. International Journal of Social, Management, Economics and Business Engineering, 8, 786-791. https://doi.org/10.5281/zenodo.1091774

Hanafiah, M.H., Azman, I., Jamaluddin, M.R. \& Aminuddin, N. (2016). Responsible tourism practices and quality of Life: Perspective of Langkawi island communities. Procedia - Social and Behavioral Sciences, 222, 406-413. https://doi.org/10.1016/j.sbspro.2016.05.194

Harrison, D. (1996). Sustainability and Tourism: Reflections from a Muddy Pool. Sustainable Tourism in Islands and Small States. Issues and Policies. Pinter Publishers, London, 69-89. https://doi.org/10.1079/9781789245899.0061

Husbands, W. \& Harrison, L.C. (1996). Practising responsible tourism: Understanding tourism today to prepare for tomorrow. Practising Responsible Tourism: International Case Studies in Tourism Planning, Policy and Development, 1-15. https://doi.org/10.1177/004728759703500417

Jamal, T.B. \& Getz, D. (1995). Collaboration theory and community tourism planning. Annals of tourism research, 22 (1), $186-204$. https://doi.org/10.1016/0160-7383(94)00067-3

Jeon, M.M., Kang, M. \& Desmarais, E. (2016). Residents' perceived quality of life in a cultural-heritage tourism destination. Applied Research Quality Life, 11, 105-123. https://doi.org/10.1007/s11482-014-9357-8

Jurowski, C. \& Brown, D.O. (2001). A comparison of the views of involved versus non-involved citizens on the quality of life and tourism development issues. Journal of Hospitality \& Tourism Research, 25 (4), 355-370. https://doi.org/10.1177/109634800102500401

Kasim, A. (2006). The need for business environmental and social responsibility in the tourism industry. International journal of hospitality \& tourism administration, 7 (1), 1-22. https://doi.org/10.1300/J149v07n01_01

Kim, K. (2002). The effects of tourism impacts on quality of life of the residents in thecommunity. Ph.D. thesis. Virginia Polytechnic Institute and State University, Department of Hospitality and Tourism Management. 
Kim, K., Uysal, M. \& Sirgy, M.J. (2013). How does tourism in a community impact the quality of life of community residents? Tourism management, 36, 527-540. https://doi.org/10.1016/j.tourman.2012.09.005

Koufteros, X.A. (1999). Testing a model of pull production: A paradigm for manufacturing research using structural equation modelling. Journal of Operations Management, 17(4), 467-488. https://doi.org/10.1016/S0272-6963(99)00002-9

Lee, T.H. (2013). Influence analysis of community resident support for sustainable tourism development. Tourism management, 34, 37-46. https://doi.org/10.1016/j.tourman.2012.03.007

Lepp, A. (2007). Residents' attitudes towards tourism in Bigodi village, Uganda. Tourism management, 28 (3), $876-885$. https://doi.org/10.1016/j.tourman.2006.03.004

Ling, L., Jakpar, S., Johari, A., Abdul Rani, N. \& Myint, K. (2011). An evaluation of the attitudes of residents in Georgetown towards the impacts of tourism development. International Journal of Business and Social Science, 2 (1), 264-277.

Liu, Y.D. (2015). Event and quality of life: A case study of Liverpool as the 2008 European capital of culture. Applied Research Quality Life, 11, 707-721. https://doi.org/10.1007/s11482-015-9391-1

Matarrita-Cascante, D., Brennan, M.A. \& Luloff, A.E. (2010). Community agency and sustainable tourism development: The case of La Fortuna, Costa Rica. Journal of Sustainable Tourism, 18 (6), 735-756. https://doi.org/10.1080/09669581003653526

Mathew, P.V. \& Sreejesh, S. (2017). Impact of responsible tourism on destination sustainability and quality of life of community in tourism destinations. Journal of Hospitality and Tourism Management, 31, 83-89. https://doi.org/10.1016/j.jhtm.2016.10.001

Mathieson, A. \& Wall, G. (1982). Tourism: Economic, Physical and Social Impacts. Harlow: Longman. https://doi.org/10.2307/634029

Mertler, C. \& Vannatta, R. (2004). Pre-Analysis Data Screening. Multivariate Statistical Methods edited by C. Mertler and R. Vannatta. Glendale, C.A. https://doi.org/10.4324/9781315266978

Moscardo, G. (2009). Tourism and quality of life: Towards a more critical approach. Tourism and Hospitality Research, 9 (2), 159-170. https://doi.org/10.1057/thr.2009.6

Mowforth, M. \& Munt, I. (1998). Tourism and sustainability: Development and new tourism in the third world. London and New York.

Ndivo, R.M. \& Cantoni, L. (2016). Rethinking local community involvement in tourism development. Annals of Tourism Research, 57, 275278. https://doi.org/10.1016/j.annals.2015.11.014

Nicholas, L., Thapa, B. \& Ko, Y. (2009). Residents' perspectives of a world heritage site: The Pitons management area, St. Lucia. Annals of Tourism Research, 36 (3), 390-412. https://doi.org/10.1016/j.annals.2009.03.005

Nunkoo, R. \& Gursoy, D. (2012). Residents' support for tourism: An identity perspective. Annals of Tourism Research, 39 (1), $243-268$. https://doi.org/10.1016/j.annals.2011.05.006

Nunnally, J. (1978). Psychometric Theory. McGraw-Hill, New York. https://doi.org/10.1177/014662167900300216

Okazaki, E. (2008). A community-based tourism model: Its conception and use. Journal of sustainable tourism, 16 (5), 511-529. https://doi.org/10.1080/09669580802159594

Rasoolimanesh, S.M., Jaafar, M. \& Tangit, T.M. (2018). Community involvement in rural tourism: a case of Kinabalu National Park, Malaysia. Anatolia, 29 (3), 337-350. https://doi.org/10.1080/13032917.2017.1412327

Sebele, L.S. (2010). Community-based tourism ventures, benefits and challenges: Khama rhino sanctuary trust, central district, Botswana. Tourism Management, 31 (1), 136-146. https://doi.org/10.1016/j.tourman.2009.01.005

Selin, S. \& Chavez, D. (1995). Developing an evolutionary tourism partnership model. Annals of Tourism Research, 22 (4), $844-856$. https://doi.org/10.1016/0160-7383(95)00017-X

Shani, A. \& Pizam, A. (2012). Community participation in tourism planning and development. Handbook of tourism and quality-of-life research. Springer, Dordrecht, 547-564. https://doi.org/10.1007/978-94-007-2288-0_32

Simpson, K. (2001). Strategic planning and community involvement as contributors to sustainable tourism development. Current Issues in Tourism, 4 (1), 3-41. https://doi.org/10.1080/13683500108667880

Smith, V.L. (1990). Alternative/responsible tourism seminar. Annals of Tourism Research, 17 (3), 479-480. https://doi.org/10.1016/01607383(90)90015-J

Spenceley, A. (2010). Tourism product development interventions and best practices in sub-Saharan Africa: Part 1. Synthesis. Washington, DC, World Bank. https://doi.org/10.13140/RG.2.1.4039.4089

Stanford, D. (2008). 'Exceptional visitors': Dimensions of tourist responsibility in the context of New Zealand. Journal of Sustainable Tourism, 16 (3), 258-275. https://doi.org/10.1080/09669580802154082

Urry, J. (2001). Globalising the tourist gaze. Tourism development revisited: Concepts, issues and paradigms, 150-160.

Wang, Y. \& Pfister, R.E. (2008). Residents' attitudes toward tourism and perceived personal benefits in a rural community. Journal of Travel Research, 47 (1), 84-93. https://doi.org/10.1177/0047287507312402

Yamane, T. (1973). Statistics: An introductory analysis.

Yu, C.P., Cole, S.T. \& Chancellor, C. (2014). Assessing community quality of life in the context of tourism development. Applied Research in Quality Life, 11, 147-162. https://doi.org/10.1007/s11482-014-9359-6

Zhou, D., Yanagida, J. F., Chakravorty, U. \& Leung, P. (1997). Estimating economic impacts from tourism. Annals of Tourism Research, 24 (1), 76-89. https://doi.org/10.1016/S0160-7383(96)00035-7

\footnotetext{
Article history: Received: 12.02.2021 Revised: 21.04.2021 Accepted: 17.06.2021 Available online: 30.06 .2021
} 